\title{
PELUANG DAN TANTANGAN PROFESI PUSTAKAWAN YANG MELEK INFORMASI DI ERA DISRUPSI (Sebuah Literature Review)
}

\author{
Zulfikar Ghazali \\ Institut Agama Islam Sultan Muhammad Syafiuddin Sambas \\ zulfikar@iaisambas.ac.id
}

\begin{abstract}
The purpose of this study is to find out how the opportunities and challenges of the librarian profession of information literacy in the era of disruption. This type of research is qualitative with a source of literature review. While this literature review is carried out with four stages consisting of: (a) focus on the discussion to be discussed; (b) linking literature with agree; (c) approve the research and (d) analyze and evaluate the critical literature reviewed based on the research discussion. For research results, in order for the librarian profession to continue to exist and survive and have opportunities in the era of disruption, it can be done in several stages: first, librarians must have competence or expertise in information literacy, second, librarians are required to always develop their potential, one of which is one of them is information literacy skills, third, librarians have the opportunity to become consultants in libraries by having several competencies or abilities such as, skills, knowledge, experience, work attitudes and public trust in the librarian. As for the challenges of the library profession, first, the challenges of adopting attitudes and learning behaviors for life. This is considered a challenge because information literacy implicitly requires an individual to be able to follow new advances in this field (information literacy), secondly, risks arising from failure to understand the concept of relationships related to information literacy, third, the magnitude of the burden and costs involved. high to build and maintain social networks that have been built.
\end{abstract}

Keywords: Disruption; Literacy; Librarian Opportunity

\begin{abstract}
ABSTRAK
Tujuan dari penelitian ini adalah untuk mengetahui bagaimana peluang dan tantangan profesi pustakawan yang melek informasi di era disrupsi. Jenis penelitian ini adalah kualitatif dengan sumber data literature review. Sedangkan kajian literature review ini dilakukan dengan empat tahapan yang terdiri dari: (a) fokus pada permasalahan yang akan diteliti; (b) menghubungkan literatur dengan permasalahan secara seimbang; (c) memasukkan pernyataan penelitian secara jelas berdasarkan metodologi di literatur; dan (d) menganalisis dan mengevaluasi secara kritis literatur yang di review berdasarkan bahasan penelitian. Untuk hasil penelitian dapat diketahui bahwa agar profesi pustakawan tetap eksis dan bertahan serta memiliki peluang pada era disrupsi, dapat dilakukan dengan beberapa tahapan: pertama, pustakawan harus memiliki kompetensi atau keahlian literasi informasi, kedua, pustakawan dituntut untuk selalu mengembangkan potensi yang dimilikinya salah
\end{abstract}


satunya adalah kemampuan literasi informasi, ketiga, pustakawan memiliki peluang untuk menjadi konsultan di perpustakaan dengan memiliki beberapa kompetensi atau kemampuan seperti, keterampilan, pengetahuan, pengalaman, sikap kerja dan kepercayaan masyarakat terhadap pustakawan tersebut. Sedangkan untuk tantangan profesi perpustakaan, pertama, tantangan mengadopsi sikap dan perilaku belajar seumur hidup. Hal ini dianggap sebagai tantangan karena literasi informasi, secara implisit menuntut seorang individu agar dapat mengikuti kemajuan baru di bidang ini (literasi informasi), kedua, risiko yang timbul dari kegagalan untuk memahami konsep hubungan terkait dengan literasi informasi, ketiga, besarnya beban dan biaya yang tinggi untuk membangun dan menjaga jaringan social yang telah dibangun. Selain itu pustakawan harus terlibat dan menjadi patner dalam proyek penelitian.

Kata Kunci: Disrupsi; Literasi; Peluang Pustakawan

\section{PENDAHULUAN}

Ketika istilah disrupsi menjadi sebuah istilah tren, terkenal atau populer, banyak sekali kegiatan-kegiatan yang diadakan baik itu dari instansi-instansi pemerintahan atau non pemerintahan, yang bertujuan untuk mengupas dan membahas istilah tersebut dan dampaknya pada kehidupan manusia saat ini. Kegiatan yang diselenggarakan dapat berupa Focus Group Discussion, workshop, dan pertemuan ilmiah. Istilah disrupsi ini sering digunakan atau dikaitkan dengan kelangsungan hidup berbagai pekerjaan atau profesi, dan menjadi sebuah tantangan untuk bertahan atau berkembang dari berbagai pekerjaan atau profesi tersebut.

Disrupsi profesi khususnya pada profesi pustakawan merupakan tantangan saat ini. Hal ini sejalan dengan Priyanto (2018) yang menjelaskan bahwa disrupsi merupakan sebuah fenomena perubahan yang sangat besar. Perubahan ini dapat menghasilkan efisiensi yang signifikan. Selain itu perubahan ini juga menimbulkan beberapa persoalan, khususnya bagi pustakawan yang tidak dapat mengikuti arus perubahan yang sangat besar dan pustakawan yang tidak atau kurang produktif, dengan kata lain pustakawan tersebut belum memiliki keinginan kuat dalam meningkatkan produktivitas khususnya dalam memberikan manfaat bagi orang lain atau yang membutuhkan. Adapun dampak dari disrupsi ini, antara lain:

1. Melambungnya atau semakin meningkatnya harga dari sebuah sumber informasi. Semakin mudahnya pencarian informasi menjadikan beberapa perusahaan atau penyedia jasa informasi melakukan pengkomersilan informasi salah satunya adalah jurnal penelitian, yang mana ketika seorang user ingin menggunakan jurnal tersebut, maka terlebih dahulu harus melanggan atau membayar kepada penyedia informasi khususnya jurnal penelitian tersebut.

2. Munculnya pilihan media akses informasi, seperti mesin pencarian informasi menjadikan user tidak perlu bersusah payah untuk datang ke perpustakaan jika ingin melakukan pencarian informasi.

3. Pergeseran pemanfaatan sumber informasi yang ada pada perpustakaan konvensional ke arah perpustakaan digital.

4. Pergeseran kebutuhan pemustaka, yang awalnya berbentuk cetak menjadi digital 
Banyak anggapan yang menyatakan bahwa penyebab dari fenomena disrupsi ini adalah perkembangan dan perubahan teknologi informasi dan komunikasi yang semakin cepat. Sekarang semua orang sadar akan kecepatan perubahan dan perkembangan teknologi serta ledakan informasi yang tidak terkendali yang melanda dan telah masuk menjadi bagian yang tidak dapat terpisahkan dalam kehidupan manusia saat. Sedikit banyaknya fenomena ini dapat mempengaruhi kehidupan yang ada dunia maupun dimuka bumi ini. Adapun perkembangan teknologi yang sangat mencolok pada zaman sekarang adalah penggunaan teknologi komputer dan teknologi informasi. Hampir disetiap kegiatan manusia tidak jauh dari penggunaan dua teknologi ini, baik dalam bertransaksi, mengerjakan tugas kuliah atau kantor, dan mencari informasi.

Perkembangan teknologi ini juga mengubah cara orang berinteraksi maupun berkomunikasi antara satu dengan yang lain dalam menjalani kehidupannya. Media sosial, perangkat seluler, dan perangkat otomatisasi yang berkembang saat ini merupakan bentuk dari perkembangan teknologi komputer dan teknologi informasi itu sendiri. Selain itu kondisi ini tentunya akan menciptakan sebuah paradigma khususnya cara pandang manusia dalam menanggapi maupun menyikapi berbagai macam hal. Perpustakaan sebagai sumber dan pusat ilmu pengetahuan dan pustakawan sebagai penggerak, sejatinya senantiasa memegang peranan penting dalam mengelola ledakan informasi di zaman ini. Untuk menghadapi hal ini, perpustakaan dan pustakawan harus bekerja keras dalam mencari seberapa besar perannya dalam era disrupsi sekarang ini, dan mencari solusi agar dapat beradaptasi, bersinergi maupun berkolaborasi dengan perubahan-perubahan tersebut.

Saat ini telah terjadi perubahan terhadap berbagai tatanan umum dan kebiasaan baru. Fenomena baru ini sudah menjadi bagian hidup sehari-hari. Untuk itu, perpustakaan perlu melakukan berbagai perubahan yang dapat berkontribusi dalam perubahan yang telah terjadi yaitu tidak lagi hanya berorientasi pada resources (koleksi) dan tempat (ruang koleksi dan layanan), namun juga sumber daya manusia (pustakawan). Selain itu status eksistensi pustakawan dipertanyakan bahkan sempat masuk daftar profesi yang akan hilang di masa yang akan datang. Profesi pustakawan saat ini harus mampu bertahan di era perkembangan teknologi yang tidak terkendali, dan ancaman dari disrupsi yang selalu menghantui profesi ini. Mengembangkan kompetensi atau kemampuan, dan membuat terobosan baru merupakan alternatif utama bagi pustakawan untuk mencapai keberhasilan. Selain itu sebagai pilar pendidikan melalui diseminasi informasi, pustakawan harus ikut andil dalam membangun masyarakat, untuk menuju masyarakat berperadaban tinggi yang mampu membedakan dan mencari kebenaran dari informasi, apakah informasi tersebut dapat dipercaya atau tidak (hoak) (Junaedi, 2019).

Berdasarkan penjelasan tersebut dapat dipahami bahwa, di era perkembangan teknologi dan ledakan informasi saat ini akan memiliki atau membawa sebuah dampak yang signifikan salah satunya yaitu perubahan pada ruang kerja dan cara bekerja itu sendiri. Ketika perpustakaan maupun pustakawan dituntut untuk serba cepat dalam memberikan pelayanan kepada pemustaka, dan jika perpustakaan maupun pustakawan tersebut tidak mampu untuk mengikuti pola-pola perubahan tersebut maka, kemungkinan besar akan banyak pekerjaanpekerjaan pustakawan yang ada diperpustakaan tergantikan dengan sebuah robot atau sebuah program 
Terdapat isu atau berita yang cukup membuat kekhawatiran yang terkait dengan disrupsi pustakawan di era perkembangan teknologi dan ledakan informasi saat ini, salah satunya adalah munculnya surat edaran No.102318/A2.3/KP/2017 tentang penataan administrasi jabatan fungsional di lingkungan Kemenristekdikti, yang mana surat edaran ini menghancurkan memupuskan harapan pustakawan, hal ini disebabkan isi dari redaksi surat tersebut pada poin 2 yang mesebutkan "Khusus bagi kenaikan pejabat fungsional tingkat ahli madya menjadi pejabat fungsional tingkat ahli utama tidak perlu diusulkan karena tidak sesuai dengan peraturan Menteri Riset, Teknologi, dan Pendidikan Tinggi No. 49 Tahun 2015". Selain itu hal ini akan menyebabkan timbulnya keresahan bagi profesi pustakawan, keresahan-keresahan ini akan membuat kreativitas para pustakawan menjadi mati dan bahkan lebih buruknya dapat membunuh profesi pustakawan yang masih ada hingga saat ini. Maka dari itu, harapan terbesar dari pustakawan adalah bagaimana pemerintah atau Lembaga yang berwenang untuk segera mengevaluasi kebijakan tersebut.

Fenomena perkembangan dan perubahan teknologi yang begitu cepat, ledakan informasi yang tidak terkendali serta isu-isu tentang disrupsi profesi yang hadir di tengah masyarakat khususnya profesi pustakawan pada zaman ini perlu diperhatikan dan disikapi dengan serius. Hal ini dapat dilakukan dengan cara mempersiapkan diri seperti mengasah dan meningkatkan kemampuan atau kompetensi diri. Agar dapat menghadapi dan bertahan pada fenomena tersebut diperlukan sebuah kemampuan untuk menghadapi fenomena tersebut, salah satunya adalah kemampuan literasi informasi. Definisi literasi informasi telah dikenal di bidang ilmu perpustakaan pada umumnya, namun lebih dari itu, istilah literasi informasi pun telah meluas penggunaannya ke berbagai bidang atau disiplin ilmu lainnya. Beragamnya format dan jenis sumber informasi serta kemudahan akses informasi akibat perkembangan dari teknologi dan ilmu pengetahuani, menjadi sebuah tantangan tersendiri bagi seorang individu untuk memenuhi kebutuhan informasinya saat ini. Selaras dengan pentingnya kehadiran dari literasi informasi, keberadaan dari lembaga terkait sebagai unit pendukung yang berhubungan dengan bidang informasi juga perlu diperhatikan (Sumanti dan Fauziah, 2017).

Literasi informasi merupakan sebuah modal bagi manusia dalam menghadapi era ledakan informasi, khususnya dalam menyesuaikan hidup pada perkembangan teknologi informasi serta dapat mencapai atau meraih kehidupan yang lebih produktif. Menurut Setyowati (2015) literasi informasi idealnya atau seharusnya menjadi sebuah keahlian maupun kemampuan yang dikuasai masing-masing individu, dikarenakan keahlian atau kemampuan ini akan membantu manusia dalam menghadapi era dimana teknologi komunikasi dan ledakan informasi yang semakin tidak terkendali, untuk mencapai hidup yang lebih berkualitas dan lebih produktif. Maka dari itu keahlian atau kemampuan literasi informasi ini menjadi bagian penting yang harus dimiliki masing-masing individu sebagai modal dalam menghadapi fenomena tersebut. Selain itu, membicarakan atau membahas modal manusia artinya membicarakan atau membahas tentang keahlian atau kemampuan produktivitas yang dimiliki individu.

Literasi informasi merupakan salah satu kompetensi atau kemampuan yang harus dimiliki dan tidak boleh dianggap remeh oleh profesi pustakawan. Pustakawan yang menguasai literasi informasi atau yang biasa dikenal dengan kemampuan melek informasi ini, 
akan memiliki kemamampuan khususnya dalam menentukan kebutuhan informasi yang diperlukan, melakukan pencarian atau menemukan informasi yang sesuai dengan kebutuhan, mengevaluasi informasi yang ditemukan, dan menggunakan informasi sesuai dengan kebutuhan atau keperluan dan ketentuan yang telah ditentukan. literasi informasi atau melek informasi ini merupakan suatu siklus yang selalu berulang, dengan pengertian bahwa di mana setelah melakukan proses menentukan, mencari, mengevaluasi hingga menggunakan informasi tersebut, maka akan memunculkan sebuah informasi yang baru atau informasi yang lain yang akan dicari menggunakan proses tersebut. Kemampuan ini akan menjadi senjata atau alat yang dibutuhkan oleh pustakawan dalam menghadapi era disrupsi saat ini (Wicaksono, 2016).

Pentingnya kemampuan literasi informasi pada saat ini, perlu mendapatkan perhatian yang lebih serius diranah pendidikan. Menurut Sandercock (2016), transisi ke era informasi menjadikan keterampilan melek informasi atau literasi informasi menjadi poin tambahan yang diperlukan di tempat kerja dan masyarakat luas. Akibatnya, dengan fenomena ini literasi informasi harus dihadirkan secara signifikan, dalam lingkungan atau dunia pendidikan. Walaupun demikian menurut Shannon, C., Reilly, J. dan Bates, J. (2019), literasi informasi bukan konsep terkenal di sektor pendidikan, tetapi memandang profil keterampilan literasi informasi sebagai keterampilan pembelajaran seumur hidup, menjadikan kemampuan ini penting untuk ditingkatkan.

Berdasarkan penjabaran tersebut dapat dipahami bahwa konsep atau istilah literasi informasi ini dibuat dengan tujuan agar seseorang dapat meningkatkan kemampuannya dalam melakukan identifikasi atau rekognisi sebuah informasi, mencari dan menggali informasi serta menerapkan atau mengaktualisasikan sumber-sumber informasi tersebut dalam seluruh aktivitas yang mereka lakukan. Selain itu banyak dari perpustakaan baik itu berbentuk formal maupun tidak, mengimplementasi konsep literasi ini pada perpustakaan.

Saat ini istilah literasi informasi mulai berkembang menjadi berbagai macam definisi. Berikut definisi tentang literasi informasi dari berbagai sumber: (1) Information Literacy is the adoption of appropriate information behaviour to identify, through whatever channel or medium, information well fitted to information needs, leading to wise and ethical use of information in society (Webber, 2010). Jika diartikan dengan bebas maka Literasi Informasi adalah sebuah proses dalam mengadopsi perilaku khususnya dalam perilaku informasi yang tepat dalam mengidentifikasi sebuah informasi yang sesuai dengan kebutuhan dan mengarah pada penggunaan informasi secara etis dan bijak baik bagi diri sendiri maupun dalam masyarakat, melalui saluran atau media apa pun. (2) "Information Literacy skills are necessary for people to be effective lifelong learners and to contribute in knowledge societies. Access to information is a human right and IL is essential in order for people to exercise this right" (Lange, J, Canuel, R. dan Fitzgibbons, M, 2011). Jika diartikan secara bebas maka, keterampilan literasi informasi diperlukan bagi orang untuk menjadi pembelajaran seumur hidup dalam mencari dan menambah ilmu pengetahuan secara efektif agar dapat berkontribusi dalam masyarakat. Selain itu akses ke sumber informasi adalah hak asasi manusia maka dari itu kemampuan literasi informasi menjadi sangat penting agar orang dapat menggunakan hak ini.

Berdasarkan penjabaran tentang definisi literasi informasi dapat dipahami bahwa literasi informasi merupakan sebuah proses mengadopsi perilaku informasi yang tepat dalam 
mengidentifikasi sebuah informasi, untuk menjadi pembelajaran seumur hidup untuk mencari dan menambah ilmu pengetahuan secara efektif dalam menggunakan atau memanfaatkan informasi secara etis dan bijak, baik bagi diri sendiri maupun untuk berkontribusi dalam masyarakat. Selain itu kemampuan literasi informasi sangat diperlukan oleh setiap individu terlebih lagi bagi profesi pustakawan, hal ini dikarenakan dengan perkembangan teknologi yang kian canggih khususnya pada bidang teknologi informasi, masih menimbulkan sebuah masalah khususnya pada otoritatif sebuah informasi.

Literasi informasi sangat erat hubungannya dengan berpikir kritis. Hal ini sejalan atau sesuai dengan pendapat Wright yang menyatakan bahwa "Additionally, one cannot be information literate without the development of related skills such as critical thinking" (Wright, 2014). jika diartikan secara bebas maka, seorang individu tidak akan memiliki keahlian atau kemampuan literasi informasi tanpa pengembangan keahlian atau keterampilan terkait seperti berpikir kritis. Lebih lanjut Wright (2014) juga menjelaskan pentingnya kemampuan literasi informasi bagi seorang pekerja, hal ini berdasarkan laporan yang diterbitkan pada tahun 1991 oleh Departemen Tenaga Kerja Amerika Serikat yang dikenal dengan sebutan SCANS (Secretary's Commission on Achieving Necessary Skills), menjelaskan bahwa organisasi - organisasi yang ada seperti National Forum on Information Literacy dan Project Information Literacy telah menekankan perlunya pekerja yang memiliki kemampuan literasi informasi.

\section{METODE PENELITIAN}

Penelitian dengan sumber data literature review memiliki dua jenis yaitu literature review kuantitatif dan literature review kualitatif. Creswell (2010) memberikan gambaran perbedaan antara literature review kualitatif dan kuantitatif sebagai berikut:

Tabel 1. Literature review kualitatif dan kuantitatif

\begin{tabular}{l|l|l}
\hline $\begin{array}{c}\text { Perbedaan dalam } \\
\text { hal }\end{array}$ & \multicolumn{1}{c|}{$\begin{array}{c}\text { Penelitian } \\
\text { Kuantitatif }\end{array}$} & \multicolumn{1}{c}{$\begin{array}{c}\text { Penelitian } \\
\text { Kualitatif }\end{array}$} \\
\hline $\begin{array}{l}\text { Jumlah literatur yang } \\
\text { dikutip pada awal } \\
\text { penelitian }\end{array}$ & $\begin{array}{l}\text { Banyak } \\
\text { (substansial) }\end{array}$ & Sedikit (minimal) \\
\hline $\begin{array}{l}\text { Penggunaan literatur } \\
\text { pada awal penelitian }\end{array}$ & $\begin{array}{l}\text { Diperlukan untuk } \\
\text { Menjustifikasi atau } \\
\text { pembenaran } \\
\text { penelitian. }\end{array}$ & $\begin{array}{l}\text { Diperlukan untuk } \\
\text { Menjustifikasi atau } \\
\text { pembenaran } \\
\text { penelitian }\end{array}$ \\
& $\begin{array}{l}\text { Memberikan dasar } \\
\text { pemikiran untuk }\end{array}$ & \\
& $\begin{array}{l}\text { arah penelitian } \\
\text { (Yaitu tujuan dan } \\
\text { pertanyaan }\end{array}$ & \\
\hline
\end{tabular}




\begin{tabular}{l|l|l}
\hline & $\begin{array}{l}\text { penelitian atau } \\
\text { hipotesis) }\end{array}$ & \\
\hline $\begin{array}{l}\text { Penggunaan literatur } \\
\text { pada akhir penelitia }\end{array}$ & $\begin{array}{l}\text { Menegaskan atau } \\
\text { tidak predeksi } \\
\text { sebelumnya dari } \\
\text { literatur }\end{array}$ & $\begin{array}{l}\text { Mendukung atau } \\
\text { memperbarui } \\
\text { temuan yang telah } \\
\text { ada di dalam } \\
\text { literatur. }\end{array}$ \\
\hline
\end{tabular}

Sumber: Creswell (2010)

Pada penelitian ini, peneliti menggunakan jenis penelitian kualitatif dengan sumber data literature review. Literatur disini merupakan atau dapat diartikan sebagai sumber ataupun acuan yang digunakan dalam berbagai macam aktivitas di dunia pendidikan ataupun aktivitas lainnya. Literatur juga dapat diartikan sebagai rujukan yang digunakan untuk mendapatkan informasi tertentu. Literatur dapat berupa buku ataupun berbagai macam tulisan lainnya seperti jurnal penelitian proseding, artikel atau paper penelitian (Suwandi, 2017). Selain itu literature review adalah sebuah proses memeriksa, mengevaluasi, dan mengkritik literatur tentang suatu topik. Dalam konteks ini, merujuk pada sumber informasi akademik seperti buku, bab buku, artikel jurnal peer-review, makalah konferensi, tesis dan disertasi (Manchester Metropolitan University, 2019). Pada penelitian ini, peneliti tidak hanya sebatas membaca literatur tetapi melakukan analisis dan sintesis secara mendalam untuk melakukan evaluasi secara kritis berdasarkan literatur yang dirujuk

Menurut Nasution (2017), terdapat empat langkah untuk melakukan penelitian literatur review, dan menjadi panduan bagi para peneliti seperti:

1. Mencari literatur yang sesuai dengan masalah yang akan dikaji atau diteliti dengan cara memindai literatur secara efisien, baik menggunakan metode manual maupun online dari sumber informasi. Tahap ini dilakukan dengan memulai penilitian dengan mempersempit topik penelitian untuk mempermudah penelusuran literatur. Peneliti memilih istilah kunci dengan menggunakan satu atau dua kata atau satu prase singkat.

2. Menilai literatur melalui sejumlah kriteria, termasuk sumbernya sendiri, penulis dan subjek. Tahap ini dilakukan untuk melihat kredibilitas dari literatur yang peneliti rujuk dan gunakan, yang bertujuan agar penelitian ini dapat diakui dan dapat dipertanggungjawabkan.

3. Memeriksa dan menganalisis isi literatur secara sistematis. Tahap ini dilakukan peneliti untuk memilah mana literatur yang tepat untuk dimasukkan ke dalam kajian yang akan atau sedang diteliti. Selain itu hal ini perlu dilakukan agar tidak membuang halaman dengan teori yang saling tumpang tindih dan menumpuk.

4. Mensintesis isi literatur secara kritis dan mendalam dari literatur seperti buku atau paperpaper yang di review.

Beberapa literatur yang menjadi dasar dilakukannya kajian ini, yaitu:

1. Buku yang berjudul Library and Information Sciences: Trend and Research (Chuanfu Chen and Ronald Larsen, 2014) 
2. Buku yang berjudul Information Literacy Concepts: An Open Educational Resource (David Hisle dan Katy Webb, 2017)

3. Artikel jurnal yang berjudul Literasi Informasi dilihat dari Perspektif Modal Manusia (Lis Setyowati, 2015). Selain itu untuk memperkuat argumen penelitian ini, dan hasil analisis isi dari ketiga literatur tersebut maka diperlukan dukungan dari literatur lain dan argumen penulis. Hasil analisis tersebut kemudian menjadi dasar pembahasan dan kesimpulan kajian ini.

\section{HASIL DAN PEMBAHASAN}

Hampir disetiap sektor pekerjaan mengalami dampak dari perkembangan teknologi, dan dampak yang paling utama dan menjadi kekhawatiran setiap individu yaitu profesi mereka yang tergantikan oleh teknologi, salah satu contoh adalah pekerjaan orang yang menunggu atau menjaga pintu tol. Dulu kebutuhan akan SDM yang bekerja di pintu jalan tol sangatlah banyak, hal ini bertujuan untuk mengatur arus kendaraan agar tidak terjadi kemacetan. Tetapi bagaimana dengan sekarang, hampir seluruh pekerja yang bekerja di pintu tol tergantikan dengan teknologi salah satunya adalah alat pembaca barcode, yang mana sebuah alat kecil yang dapat melakukan pekerjaan operasional pada pintu tol. Kemudian timbul sebuah pertanyaan, apakah profesi pustakawan akan mengalami hal yang sama seperti pekerja yang bekerja di pintu tol.

Perkembangan teknologi ini juga mengubah cara orang berinteraksi maupun berkomunikasi antara satu dengan yang lain dalam menjalani kehidupannya. Media sosial, perangkat seluler, dan perangkat otomatisasi yang berkembang saat ini merupakan bentuk dari perkembangan teknologi komputer dan teknologi informasi itu sendiri. Selain itu kondisi ini tentunya akan menciptakan sebuah paradigma khususnya cara pandang manusia dalam menanggapi maupun menyikapi berbagai macam hal. Perpustakaan sebagai sumber dan pusat ilmu pengetahuan dan pustakawan sebagai penggerak, sejatinya senantiasa memegang peranan penting dalam mengelola ledakan informasi di zaman ini. Untuk menghadapi hal ini, perpustakaan dan pustakawan harus bekerja keras dalam mencari seberapa besar perannya dalam era disrupsi sekarang ini, dan mencari solusi agar dapat beradaptasi, bersinergi maupun berkolaborasi dengan perubahan-perubahan tersebut

Permasalahan yang muncul akibat fenomena ini bukan saja tentang bagaimana kemampuan perpustakaan maupun pustkawan dalam menyimpan baik itu menyimpan bahan pustaka maupun informasi, tetapi yang menjadi pertanyaan penting adalah bagaimana cara perpustakaan maupun pustakawan mengolah, mengklasifkasikan, menelusuri, dan menjaga serta mengamankan baik itu bahan pustaka maupun informasi. Hal ini sejalan dengan pendapat Batubara (2015) yaitu, saat ini pustakawan dituntut tidak hanya terampil mengurusi buku atau jenis media informasi lain. Namun dituntut bisa menguasai penelusuran literasi informasi yang menjadi sebuahterobosan baru dan tantangan ke depan bagi pustakawan dalam mengemban tugas mulia untuk mengelola informasi yang ada di perpustakaan dimana pustakawan tersebut bekerja. Dengan demikian, pustakawan harus mempunyai komitmen dengan penuh kesadaran agar dapatmengakses, memahami dan 
memanfaatkan informasi yang diperoleh untuk dikomunikasikan kepada masyarakat yang membutuhkan

Maka dari itu, di era perkembangan teknologi dan ledakan informasi saat ini akan memiliki atau membawa sebuah dampak yang signifikan salah satunya yaitu perubahan pada ruang kerja dan cara bekerja itu sendiri. Ketika perpustakaan maupun pustakawan dituntut untuk serba cepat dalam memberikan pelayanan kepada pemustaka, dan jika perpustakaan maupun pustakawan tersebut tidak mampu untuk mengikuti bentuk atau pola-pola perubahan tersebut maka, kemungkinan besar akan banyak pekerjaan-pekerjaan pustakawan yang ada diperpustakaan tergantikan dengan teknologi itu sendiri, baik itu berupa robot maupun sebuah aplikasi (program), sebagai contoh pada layanan sirkulasi, salah satu tugas dari layanan sirkulasi yaitu layanan peminjaman dan pengembalian bahan pustaka sudah diambil alih sebuah robot atau aplikasi (program). Hal ini disebabkan di sebagian perpustakaan yang ada sudah menerapkan sistem, yang mana pemustaka tidak perlu lagi kebagian layanan sirkulasi untuk melakukan peminjaman atau pengembalian bahan pustaka, karena pemustaka cukup meletakan bahan pustaka yang ingin dipinjam atau dikembalikan pada sebuah device, alat atau mesin yang telah disiapkan oleh perpustakaan dan didesain khusus untuk melakukan tugas layanan tersebut.

Merambahnya produk dari perkembangan teknologi ini seperti mesin pencari informasi google, smartphone dan layanan internet menjadi tantangan tersendiri bagi setiap sektor baik itu milik pemerintah maupun swasta yang bergerak di bidang sosial, ekonomi, pendidikan dan sebagainya, khususnya pada rumah pustakawan itu sendiri yaitu perpustakaan. Munculnya isu-isu tentang profesi yang terdisrupsi dan tergantikan oleh teknologi juga, menjadi sebuah kekhawatiran, ancaman bahkan menjadi mimpi buruk bagi profesi pustakawan itu sendiri. Tetapi jika dilihat hingga saat ini, profesi pustakawan masih tetap eksis dan semakin berkembang, hal ini dibuktikan dengan banyaknya perpustakaan yang ada hampir di setiap tempat. Selain itu banyaknya perguruan tinggi yang membuka jurusan atau program studi khususnya yang berhubungan dengan ilmu perpustakaan dan informasi, baik itu diploma, strata satu, pascasarjana bahkan program doktoral.

Banyak dari pustakawan lama atau senior yang telah digantikan oleh pustakawan baru, yang mana pustakawan baru tersebut berasal dari generasi $Y$ atau biasa disebut dengan generasi milenial, sehingga kemampuan dan pengetahuannya tentang teknologi informasi dan komunikasi dapat menjadi modal awal dalam menghadapi era disrupsi saat ini. Generasi Y merupakan sebutan untuk generasi millenial (Andrea, Gabriella \& Time, 2016). Lebih lanjut Angeline (2011) menjelaskan bahwa Generasi ini tumbuh bersama berkembangnya teknologi sehingga mereka menjadi mahir dalam mengakses informasi dengan cepat menggunakan teknologi.

Sejalan dengan hal tersebut Munir (2018) berpendapat bahwa, semenjak perkembangan teknologi informasi dan komunikasi digital ini menjadi tidak terkendali dan dijadikan sebagai sebuah sarana untuk memenuhi kebutuhan dan selalu mendampingi setiap aktifitas individu, maka sejak saat itu pula dimulainya babak baru peradaban manusia. Babak baru ini ditandai sebagai munculnya generasi $\mathrm{Y}$ atau generasi milenial, yakni generasi yang melihat cara pandang teknologi informasi dan komunikasi salah satunya teknologi internet sebagai temuan yang bisa mengubah segalanya, karena generasi ini meyakini bahwa sarana 
akses informasi bisa diperoleh tanpa batas, komunikasi juga tidak harus dilakukan secara tatap muka langsung, dan semua orang dapat mempelajari dan membagikan keilmuan dengan mudah tanpa bertatap muka secara langsung. Generasi milenial saat ini sudah jauh berubah dari generasi sebelumnya, hal ini disebabkan oleh perubahan cara pandang generasi milenial dan generasi yang lama terhadap perkembangan teknologi informasi dan komunikasi saat ini. Hal ini juga yang menjadikan generasi milenial ini memiliki kekhasan atau ciri yang berbeda dalam memahami realitas kehidupan. Secara kelebihan generasi ini lebih mengerti teknologi, mudah mengakses banyak perkembangan isu yang terjadi dimasyarakat, mengakses banyak informasi yang menunjang sumber petengahuan secara mudah melalui akses internet.

Krishnan, Bopaiah, Bajaj, dan Prasad (2012) menjelaskan bahwa generasi millenial (terdiri sekitar 27,5\% dari tenaga kerja), sebagian besar menyukai media yang interaktif dan sosial seperti video, audio dan media sosial lainnya. Paramitha dan Ihalauw (2018) berpendapat bahwa generasi milenial berbeda dengan generasi sebelumnya, generasi milenial ini tumbuh dengan akses yang lebih besar terhadap informasi dan perkembangan teknologi, serta memanfaatkan media jejaring sosial sebagai bahan aktifitas sehari-hari. Hal ini menimbulkan persepsi dan karakteristik yang berbeda dengan generasi sebelumnya. Lebih lanjut Dalam bekerja, Generasi milenial memiliki karakteristik peduli dengan teknologi baru, aktif mencoba hal-hal baru, bersifat individualis egosentris, tidak peduli, dan cepat bosan, serta memiliki kecenderungan yang rendah terhadap komitmen dan kesetiaan mereka dalam bekerja (Chandra ,D. O, Hubeis, A. V. S \& Sukandar, D., 2017)

Berdasarkan penjabaran tersebut dapat dipahami bahwa pertama, profesi pustakawan masih memiliki peluang untuk tetap eksis dan bertahan di era disrupsi seperti saat ini salah satunya dengan cara memiliki kemampuan literasi informasi, meningkatkan kemampuan dan kompetensi pustakawan, serta menjadi konsultan perpustakaan (Horton, 2014). Pustakawan generasi $Y$ atau milenial memiliki peluang besar untuk tetap unggul di era disrupsi saat ini. Di samping generasi ini memiliki sifat negatif seperti individualis egosentris, tidak peduli, dan cepat bosan, serta memiliki kecenderungan yang rendah terhadap komitmen dan kesetiaan mereka dalam bekerja, generasi ini memiliki kelebihan dalam memahami, mengakses atau menggunakan teknologi informasi dan komunikasi yang semakin tidak terkendala perkembangannya. Walaupun demikian, untuk dapat meraih peluang tersebut maka hal pertama yang harus dilakukan adalah memiliki kemampuan atau kompetensi, salah satunya adalah kemampuan literasi informasi atau melek informasi. Setiap individu yang melek informasi akan memiliki peluang lebih tinggi untuk eksis dan bertahan dalam era disrupsi. Banyak dari perusahaan baik itu swasta maupun pemerintah meyakini bahwa tenaga kerja yang memiliki kemampuan literasi informasi atau biasa disebut dengan melek informasi, akan bekerja lebih cerdas dalam hal apa pun dan dapat menghasilkan produk-produk yang berkualitas, hal ini juga berlaku bagi profesi pustakawan.

Kedua, dengan keahlian atau kemampuan melek informasi yang dimiliki oleh pustakawan, akan memberikan atau memiliki peluang untuk mendapatkan penghasilan yang lebih baik. Setiap individu memiliki kemampuan, hanya saja individu tersebut masih belum tahu atau tidak mau meningkatkan potensi pada dirinya, khususnya bagi pustakawan. Jangan malu atau ragu untuk meningkatkan potensi diri. Singkatnya, jika seseorang individu khususnya pustakawan, ingin bertahan dan tidak terdisrupsi, maka kemampuan atau potensi 
pada diri pustakawan tersebut juga harus ditingkatkan, dimulai dari tahap pemula, lalu naik ke tingkat menengah, dan kemudian, cepat atau lambat, naik ke tingkat lanjutan atau lebih tinggi. Jika melihat dari layanan yang ada diperpustakaan, profesi pustakawan masih memiliki peluang besar untuk tetap eksis, karena tidak semua layanan yang ada di perpustakaan dapat digantikan oleh teknologi (robot).

Terdapat bermacam-macam layanan yang ada dan dapat ditemukan di di perpustakaan, seperti (Hisle dan Webb, 2017): (1)Layanan Akses adalah departemen utama di perpustakaan mana pun, meskipun kadang-kadang disebut dengan layanan sirkulasi. Layanan ini memberikan pemustaka sarana untuk dapat mengakses koleksi perpustakaan, artinya pada bagian ini, akan dilakukan pemeriksaan terhadap koleksi perpustakaan baik itu yang masuk maupun yang keluar, dan pemeliharaan catatan peminjaman koleksi perpustakaan. Catatan peminjaman koleksi perpustakaan, dan akun sistem perpustakaan, biasanya hanya tersedia untuk staf layanan akses. Dengan kata lain, jika seseorang atau pemustaka memiliki pertanyaan yang berhubungan dengan akun sistem perpustakaan, atau ingin memeriksa koleksi perpustakaan seperti buku, atau ingin membayar denda, maka layanan akses inilah tempatnya. (2)Referensi atau layanan referensi merupakan layanan yang membantu pemustaka dalam menemukan informasi sesuai dengan kebutuhan pemustaka. Layanan refensi ini merupakan layanan yang menuntut pustakawan untuk memahami kebutuhan pemustaka, jadi kemampuan literasi informasi pustakawan pada layanan ini sangat diperlukan. Layanan refereni juga merupakan solusi bagi pemustaka ketika mengalami kebingungan baik itu dalam mencari informasi, atau dalam penyelesaian proyek yang sedang mereka kerjakan seperti penelitian, tugas akhir dan sebagainya. Di beberapa perpustakaan biasanya meja layanan referensi dikombinasikan dengan layanan jasa. Pustakawan yang ada pada layanan referensi, harus selalu meningkatkan kemampuan dan kompetensinya, karena bagi pemustaka, layanan referensi perpustakaan merupakan tempat terbaik dan menjadi alternatif utama dalam mencari informasi tentang suatu topik. Untuk dapat memberikan pelayanan maksimal kepeada pemustaka, maka perpustakaan harus memiliki pustakawan dengan bidang keahlian khusus atau tertentu, minimal pustakawan yang memiliki kemampuan literasi informasi. (3)Layanan teknis dan temu kembali informasi, sebagian besar mengacu pada akuisisi dan data log, dengan mengintegrasikan buku-buku dan jurnal terakhir kedalam koleksi perpustakaan. Selain itu pustakawan yang bekerja di layanan ini jarang dilihat oleh pemustaka, karena mereka biasanya tidak mempunyai peran, khususnya pada layanan public. Walaupun begitu, mereka memiliki peranan penting dalam perkembangan perpustakaan, khususnya dalam bidang pengembangan dan pemeliharaan system atau alat pencari informasi, yang dikenal dengan mesin temu balik informasi seperti OPAC.

Pada era disrupsi dan perkembangan teknologi informasi saat ini, layanan perpustakaan dan peranan pustakawan mengalami pergeseran, dari yang semula perpustakaan hanya berbasis pada layanan konvensional sedikit demi sedikit bergeser pada layanan yang berbasis pada teknologi informasi. Tentunya dengan tuntutan yang demikian diharapkan pustakawan semakin menyadari bahwa tugas yang diemban penuh dengan tantangan, kompetansi dan juga permasalahan yang kompleks. Walaupun demikian, kemajuan dan perkembangan teknologi informasi ini dan penerapannya di perpustakaan, tentunya akan menjadi sebuah alternatif yang sangat membantu pustakawan dalam 
meningkatkan layanan yang diberikan kepada pemustakanya. Oleh karena itu, pustakawan juga harus berkompeten dalam penguasaan ICT (Information Communication Technology). Kompetensi mendasar yang harus dimiliki pustakawan berkaitan hal diatas yaitu memiliki kemampuan dalam penggunaan komputer, kemampuan dalam mengoperasikan basis data yang diterapkan di perpustakaan, kemampuan dalam penggunaan jaringan dan kemampuan dalam pengoperasian internet (Rifngati, 2016).

Berdasarkan penjabaran tentang layanan pada perpustakaan maka, dapat di fahami bahwa setiap pustakawan memiliki fungsi dan keahlian masing-masing. Namun untuk dapat bertahan dan memiliki peluang di era disrupsi saat ini, pustakawan tidak hanya harus terampil mengurusi buku atau jenis media informasi lainnya, Namun dituntut untuk menguasai berbagai macam teknik atau metode dalam melakukan penelusuran literasi informasi dan penggunaan teknologi informasi. Dengan demikian, pustakawan harus memiliki komitmen atau pendirian yang kuat untuk selalu meningkatkan potensi diri agar dapat memiliki kemampuan dalam mengakses, memahami dan memanfaatkan informasi yang diperoleh, dan mengkomunikasikan informasi tersebut kepada masyarakat yang membutuhkan serta menjadi solusi bagi pemustaka. Agar dapat menjadi solusi bagi pemustaka atau orang banyak, maka pustakawan harus memahami makna dari profesi pustakawan tersebut.

Berdasarkan hasil penelitian yang telah dilakukan oleh Heriyanto, Yusuf \& Rusmana (2013), maka terdapat delapan makna dari profesi pustakawan.

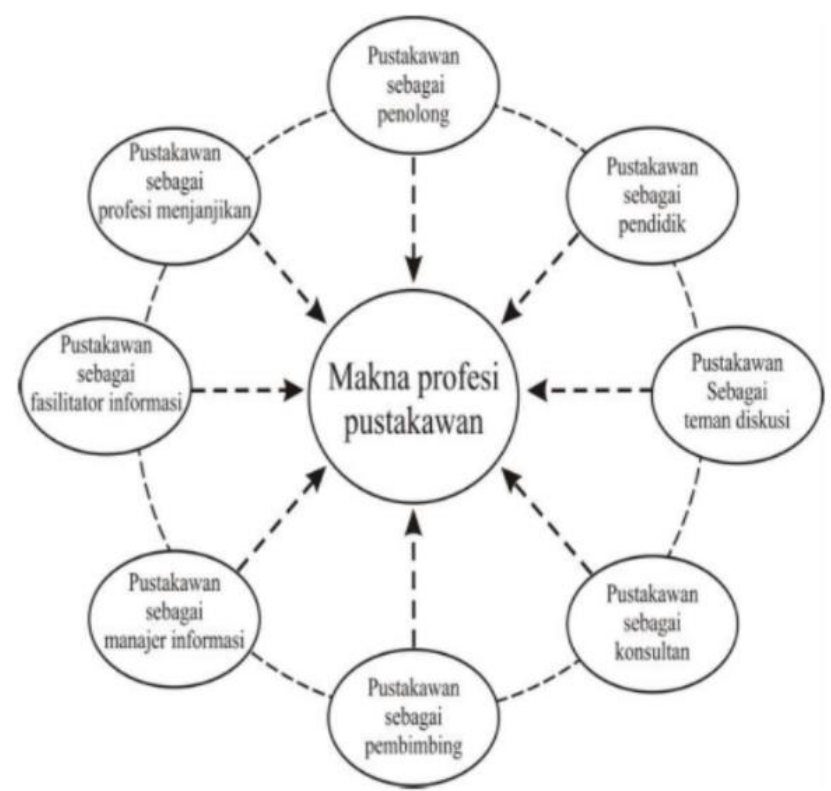

Gambar 1. Skema Makna Profesi Pustakawan

Sumber: oleh Heriyanto, Yusuf \& Rusmana (2013)

Berdasarkan skema tersebut maka dapat dilihat bahwa terdapat delapan makna dari profesi pustakawan yang terdiri dari:

1. Pustakawan sebagai penolong, yang bertujuan untuk menolong atau membantu orang lain dalam mencari atau menemukan informasi yang dibutuhkan oleh orang tersebut, baik itu dengan cara mencarikan koleksi secara langsung atau mengajarkan secara langsung cara 
mencari dan menemukan koleksi, dengan tujuan agar orang tersebut dapat mencari informasi yang dibutuhkannya secara mandiri.

2. Pustakawan sebagai pendidik, yang bertujuan untuk mengajarkan orang yang awalnya tidak tahu menjadi tahu. Hal ini biasanya dilakukan oleh pustakawan yang bekerja di lingkungan akademis baik itu sekolah maupun perguruan tinggi. Salah satu program yang dapat diajarkan oleh pustakawan adalah program literasi informasi, yang mana program ini dapat diadakan atau dilaksanakan baik itu di perpustakaan maupun bekerjasama dengan sekolah atau perguruan tinggi untuk menjadikan literasi informasi sebagai bagian mata kuliah atau mata pelajaran dari kurikulum yang ada di lingkungan akademis tersebut.

3. Pustakawan sebagai teman diskusi, yang mana seorang pustakawan yang memiliki pengetahuan dan komunikasi yang baik dapat menjadi tempat berdiskusi oleh berbagai pihak, baik itu dosen, guru, mahasiswa, murid maupun civitas akademik lainnya. Diskusi yang dilakukan tidak serta merta hanya membahas seputar mata kuliah atau mata pelajaran saja, melainkan dapat membahas tentang isu-isu atau topik-topik yang sedang tren atau viral di lingkungan masyarakat, membahas masalah politik, sosial dan budaya. Melalui kegiatan diskusi tersebut diharapkan dapat menambah wawasan dan mengasah kemampuan berbicara atau mengungkapkan pendapat serta berfikir kritis.

4. Pustakawan sebagai konsultan, yang mana dengan bekal pengetahuan yang luas, menjadikan kepakaran seorang pustakawan dapat digunakan untuk membantu orang lain dalam menganalisis, mengevaluasi serta memberikan saran dalam pengambilan keputusan.

5. Pustakawan sebagai pembimbing, yang mana dengan bekal pengetahuan yang luas pustakawan dapat menjadi pembimbing bagai mahasiswa yang bingung dalam menyelesaikan tugas akhir baik itu skripsi, tesis maupun disertasi walaupun hal ini dilakukan secara tidak formal.

6. Pustakawan sebagai manajer informasi, yang mana pustakawan memiliki tugas dan tanggungjawab berdasarkan pengalaman dan pengetahuannya untuk merancang menangani, mengolah dan menghadirkan koleksi pustaka yang dibutuhkan oleh orang lain (pemustaka) baik itu berbentuk cetak maupun digital.

7. Pustakawan sebagai fasilitator informasi, yang mana pustakawan disini berperan aktif menjadi agen informasi yang bertanggungjawab untuk mentransfer pengetahuannya kepada orang lain (pemustaka) sesuai dengan spesialisasi masing-masing.

8. Pustakawan sebagai profesi yang menjanjikan, yang mana dengan adanya fenomena ledakan informasi ini pustakawan menjadi profesi yang dibutuhkan untuk menjadi penyaring informasi yang tidak terkendali saat ini. Walaupun demikian hal ini dapat dilakukan jika pustakawan meningkatkan potensi atau kemampuannya

Ketiga, profesi pustakawan saat ini memiliki peluang untuk menjadi konsultan perpustakaan dengan kemampuan melek informasi yang dimilikinya, hal ini sejalan dengan makna profesi yang telah dijabarkan sebelumnya. Ketika kompetensi keahlian literasi informasi pustakawan meningkat, dan menjadi lebih dikenal luas baik itu di komunitas pustakawan itu sendiri maupun di luar komunitas tersebut, serta mampu memberikan solusi atas setiap permasalahan yang dihadapi oleh orang lain, menjadikan keberadaannya lebih 
bermanfaat dan menimbulkan kepercayaan masyarakat terhadap pustakawan tersebut, maka dalam hal ini pustakawan dapat disebut sebagai konsultan perpustakaan.

Sebagai seorang konsultan perpustakaan, pustakawan dituntut untuk memiliki kompetensi dan kemampuan yang memadai yang terdiri dari (Nirmala, et al., 2018):

1. Keterampilan, sebagai seorang yang terampil, pustkawan harus cekatan dan mahir dalam segala hal yang menjadi bidang pekerjaannya.

2. Pengetahuan, sebagai seorang yang berpengetahuan, pustakawan harus memiliki wawasan dan pemahaman yang matang di bidang kepustakawanan.

3. Pengalaman, sebagai seorang yang berpengalaman, pustakawan harus pernah bekerja dan melakukan berbagai kegiatan kepustakawanan, baik dalam kegiatan pengelolaan perpustakaan, penulisan dan penelitian, maupun pengembangan profesi.

4. Sikap Kerja, sedangkan sikap kerja dapat ditunjukan melalui perilaku dan kepribadian yang baik dari diri pustakawan, ia dapat memahami karakteristik pengguna dengan baik dan peka terhadap kebutuhan informasi pengguna.

Selain itu, pustakawan juga bisa menjadi konsultan penelitian atau konsultan riset, yang mana, pustakawan di sini menjadi patner dalam sebuah proyek penelitian. Salah satu peran terpenting bagi pustakawan saat ini adalah menjadi patner dalam kegiatan perguruan tinggi, hal ini sejalan dengan pendapat yaitu, pustakawan akademik harus mampu bekerjasama dengan para sivitas akademika, baik dosen maupun mahasiswa dalam berbagai kegiatan penelitian. Salah satu tugas utama pustakawan akademik adalah menjamin terselenggaranya kegiatan riset di perguruan tinggi melalui penyediaan sumber-sumber yang diperlukan dan menyelenggarakan program instruksional yang diperlukan untuk mendukung kegiatan riset (Kennedy \& Brancolini, 2012)

Berdasarkan penjabaran yang telah dilakukan tentang peluang profesi pustakawan di era disrupsi saat ini, dapat disimpulkan bahwa agar profesi pustakawan tetap eksis dan bertahan, dapat dilakukan dengan beberapa tahapan: pertama, pustakawan harus memiliki kompetensi atau keahlian literasi informasi, kedua, pustakawan dituntut untuk selalu mengembangkan potensi yang dimilikinya salah satunya adalah kemampuan literasi informasi, ketiga, pustakawan memiliki peluang untuk menjadi konsultan di perpustakaan dengan memiliki beberapa kompetensi atau kemampuan seperti, keterampilan, pengetahuan, pengalaman, sikap kerja dan kepercayaan masyarakat terhadap pustakawan tersebut. Selain itu pustakawan harus terlibat dan menjadi patner dalam proyek penelitian.

Setelah membahas peluang berikut tantangan profesi pustakawan pada era perkembangan teknologi saat ini dapat dilihat bahwa tantangan profesi pustakawan bersifat eksternal dan internal. Menurut Rulyah (2018) pada tantangan eksternal, peran pustakawan bukan lagi atau tidak hanya sebatas sebagai perantara informasi baik itu dalam mencari atau mendistribusikan informasi, melainkan sebagai fasilitator informasi dan pengelola informasi. Sedangkan tantangan internal menjadikan pustakawan untuk dapat membentuk integritas kepribadian kokoh yang disebabkan oleh dampak dari akibat dari globalisasi. Tantangan ini dapat dihadapi dan diatasi atau diselesaikan jika pustakawan tak pernah berhenti mengembangkan diri dan belajar, terutama terhadap hal-hal yang baru akibat dari perubahan, ketidakmenentuan, dan kompleksitas dari keduanya. 
Selain itu terdapat tiga resiko atau tantangan bagi pustakawan yang melek informasi, adapun tantangannya sebagai berikut (Horton, 2014):

1. Tantangan mengadopsi sikap dan perilaku belajar seumur hidup. Hal ini dianggap sebagai tantangan karena literasi informasi, secara implisit menuntut seorang individu agar dapat mengikuti kemajuan baru di bidang ini (literasi informasi). Setiap hari, para ahli teori dan praktisi literasi informasi secara simultan mengembangkan ide-ide, pendekatan, strategi baik itu yang baru mampun memperbarui yang sudah ada.

2. Selanjutnya, risiko yang timbul dari kegagalan untuk memahami konsep hubungan terkait dengan literasi informasi. Masih ada perbedaan pendapat tentang apa literasi informasi itu, dan bagaimana itu harus didefinisikan. Selain itu ada banyak istilah dan kata berbeda yang digunakan untuk menggambarkan konsep yang pada dasarnya sama, seperti kompetensi informasi, kelancaran informasi, literasi digital, dan sebagainya. Kemudian ada tantangan untuk menghubungkan literasi informasi ke berbagai bidang dan disiplin ilmu yang terkait erat. Misalnya, literasi media dan literasi informasi, idealnya, harus berjalan seiring dengan kata lain antara literasi informasi dan literasi media harus saling melengkapi. Berdasarkan hal ini dapat difahami bahwa seorang individu yang melek informasi harus memiliki toleransi tertentu khususnya dalam urusan dunia multidisipliner. banyaknya disiplin ilmu baru dan perkembangan alat maupun teknologi informasi dan bagaimana mereka berhubungan antara satu dengan yang lainnya adalah bagian integral dari tantangan literasi informasi saat ini.

3. Tantangan selanjutnya adalah besarnya beban dan biaya yang tinggi untuk membangun dan menjaga jaringan sosial. Literasi informasi tidak seperti ilmu fisika atau biologi di mana satu atau dua kolega dan asisten dapat bekerja sendiri di laboratorium selama bertahun-tahun. Literasi informasi mengharuskan individu untuk membangun sebuah jaringan sosial atau rekan kerja, yang mana jaringan social tersebut berfungsi sebagai tempat berbagi, baik itu saran, kebutuhan maupun informasi yang dibutuhkan. Jaringan sosial ini juga berlaku pada ranah teknologi informasi, khususnya menggunakan teknologi internet.

Berdasarkan penjabaran yang telah dilakukan tentang tantangan profesi pustakawan yang melek informasi, dapat difahami bahwa peluang dan tantangan selalu berjalan bergandengan, artinya dimana ada peluang disitu juga ada tantangan atau resiko yang harus dihadapi. Sebagai profesi pustakawan yang ingin tetap eksis dan dapat bertahan pada era disrupsi saat ini, harus bekerja keras dalam meningkatkan kompetensi serta selalu siap dalam menghadapi segala konsekuensi maupun resiko yang muncul.

\section{SIMPULAN}

Saat ini telah terjadi perubahan terhadap berbagai tatanan umum dan kebiasaan baru. Fenomena baru ini sudah menjadi bagian hidup sehari-hari, yaitu fenomena perkembangan teknologi dan ledakan informasi. Untuk itu, perpustakaan perlu melakukan berbagai perubahan yang dapat berkontribusi dalam perubahan yang telah terjadi. Selain itu di era perkembangan teknologi dan ledakan informasi yang tidak terkendali, serta isu-isu tentang disrupsi profesi yang hadir di tengah masyarakat khususnya profesi pustakawan pada saat ini 
perlu mendapatkan perhatikan dan disikapi dengan serius, karena hal ini memiliki atau membawa sebuah dampak yang signifikan terhadap perubahan pada ruang kerja dan cara bekerja itu sendiri. Walaupun demikian hal ini dapat dihadapi dengan cara melakukan atau mempersiapkan diri seperti mengasah dan meningkatkan kemampuan atau kompetensi diri, salah satunya adalah dengan kemampuan literasi informasi.

Pustakawan generasi $Y$ atau milenial memiliki peluang besar untuk tetap unggul di era disrupsi saat ini. Disamping generasi ini memiliki sifat negatif seperti individualis egosentris, tidak peduli, dan cepat bosan, serta memiliki kecenderungan yang rendah terhadap komitmen dan kesetiaan mereka dalam bekerja, generasi ini memiliki kelebihan dalam memahami, mengakses atau menggunakan teknologi informasi dan komunikasi yang semakin tidak terkendal perkembangannya. Walaupun demikian, untuk dapat meraih peluang tersebut maka hal pertama yang harus dilakukan adalah memiliki kemampuan atau kompetensi, salah satunya adalah kemampuan literasi informasi atau melek informasi. Selain itu, sebagai profesi, pustakawan harus mengetahui makna dari profesi pustakawan itu sendiri, terdapat delapan makna profesi pustakawan yang terdiri dari pustakawan sebagai penolong, pustakawan sebagai pendidik, pustakawan sebagai teman diskusi, pustakawan sebagai konsultan, pustakawan sebagai pembimbing, pustakawan sebagai manajer informasi, pustakawan sebagai fasilitator informasi, dan pustakawan sebagai profesi yang menjanjikan.

Agar profesi pustakawan tetap eksis dan bertahan serta memiliki peluang pada era disrupsi, dapat dilakukan dengan beberapa tahapan: pertama, pustakawan harus memiliki kompetensi atau keahlian literasi informasi, kedua, pustakawan dituntut untuk selalu mengembangkan potensi yang dimilikinya salah satunya adalah kemampuan literasi informasi, ketiga, pustakawan memiliki peluang untuk menjadi konsultan di perpustakaan dengan memiliki beberapa kompetensi atau kemampuan seperti, keterampilan, pengetahuan, pengalaman, sikap kerja dan kepercayaan masyarakat terhadap pustakawan tersebut. Walaupun demikian perlu digaris bawahi bahwa, seorang individu khususnya pustakawan tidak akan memiliki keahlian atau kemampuan literasi informasi tanpa pengembangan keahlian atau keterampilan terkait, yaitu keterampilan dalam berpikir kritis.

Sedangkan untuk tantangan profesi perpustakaan, pertama, tantangan mengadopsi sikap dan perilaku belajar seumur hidup. Hal ini dianggap sebagai tantangan karena literasi informasi, secara implisit menuntut seorang individu agar dapat mengikuti kemajuan baru di bidang ini (literasi informasi). Kedua, risiko yang timbul dari kegagalan untuk memahami konsep hubungan terkait dengan literasi informasi. Ketiga, besarnya beban dan biaya yang tinggi untuk membangun dan menjaga jaringan sosial yang telah dibangun. Selain itu pustakawan harus terlibat dan menjadi patner dalam proyek penelitian.

Perkembangan sains dan teknologi telah merevolusi penggunaan maupun penanganan informasi, sehingga seorang individu khususnya pustakawan dan profesi informasi lainnya, perlu melakukan percepatan dalam meninjau beberapa dari banyak risiko karir, tantangan, dan peluang yang dihadapi pustakawan dan profesi informasi lainnya sekarang. Sebagai contoh mesin pencari yang sangat cepat, praktis dan familiar telah merevolusi kemampuan orang awam untuk mencari informasi yang mereka butuhkan sendiri, baik itu menggunakan komputer ketika di rumah, menggunakan laptop ketika di tempat kerja, menggunakan smartphone atau tablet saat bepergian dan sebagainya 


\section{DAFTAR PUSTAKA}

Andrea, B. G, Horváth, C \&Time, J.(2016). "Y and Z Generations at Workplaces". Journal of Competitiveness, 8(3), p90-106. DOI: 10.7441/joc.2016.03.06

Angeline, T. (2011). Managing generational diversity at the workplace: Expectations and perceptions of different generations of employees. African Journal of Business Management, 5(2), p249-255. D0I: https://doi.org/10.5897/AJBM10.335

Batubara, A. K. (2015). Literasi Informasi di Perpustakaan. Iqra': Jurnal Perpustakaan dan Informasi, 9(1), p43-56. DOI: 10.30829/iqra.v9i1.67

Chandra ,D. O, Hubeis, A. V. S \& Sukandar, D. (2017). Kepuasan Kerja Generasi X dan Generasi Y terhadap Komitmen Kerja di Bank Mandiri Palembang. Jurnal Aplikasi Bisnis dan Manajemen, 3(1), p12-22. DOI: https://doi.org/10.17358/jabm.3.1.12

Chen, C \& Larsen, R. (2014). Library and Information Sciences: Trend and Research, Springer Heidelberg Dordrecht London New York

Creswell J. W. (2010). Research Design: Qualitative, Quantitative, and Mixed Methods Approaches, 3th, terjemahan Achmad Fawaid. Yogyakarta

Heriyanto, Yusuf, P. M \& Rusmana, A. (2013). Makna dan Penghayatan Profesi Pustakawan: Studi Fenomenologis Terhadap Para Pustakawan Pada Perpustakaan Perguruan Tinggi. Jurnal Kajian Informasi \& Perpustakaan, 1(2), p147-156. DOI: https://doi.org/10.24198/jkip.v1i2.11004

Hisle, D \& Webb, K. (2017). Information Literacy Concepts: An Open Educational Resource. Joyner Library, ECU

Horton F. (2014) "Career and Professional Opportunities and Challenges for Librarians and Other Information Professionals Specializing in Information Literacy and Lifelong Learning". In: Chen C., Larsen R. (eds) Library and Information Sciences. Springer, Berlin, Heidelberg, p3-8. DOI: https://doi.org/10.1007/978-3-642-54812-3_1

Junaedi, D. (2019). Tantangan Kepustakawanan di Era Disrupsi. Media Pustakawan, 26(3). Retrieved from https://bit.ly/35RNMPR

Kennedy, M. R., \& Brancolini, K. R. (2012). Academic librarian research: a survey of attitudes, involvement, and perceived capabilities. College \& Research Libraries, 73(5), p431-448. DOI: https://doi.org/10.5860/crl-276

Krishnan , S. K, Bopaiah, S, Bajaj, D \& Prasad, R .(2012). Organization, Generations and Communication - Infosys Experience. NHRD Network Journal, 5(4), p85-93. DOI: https://doi.org/10.1177/0974173920120414 
Lange, J., Canuel, R. \& Fitzgibbons, M. (2011). Tailoring information literacy instruction and library services for continuing education. Journal of information literacy, 5(2), p66-80. DOI: https://doi.org/10.11645/5.2.1606

Manchester Metropolitan University, Literature Reviews, Library Manchester Metropolitan University. Retrieved from https://lib guides.mmu.ac.uk/literaturereviews

Munir, M. (2018). Membingkai Kepribadian Ulul Albab Generasi Milenial. Ta'limuna, 7(1), p45-59. DOI: http://dx.doi.org/10.32478/ta.v7i1.147

Nasution, M. K. M. (2017). Penelaah Literatur. DOI: 10.13140/RG.2.2.31169.45926/1

Nirmala, W, et al. (2018). Membangun Kompetensi Profesional Pustakawan. Jawa Tengah: Yuma Pustaka

Paramitha, Y \& Ihalauw, J. J. O. I. (2018). Persepsi Generasi Y Mengenai Pekerjaan, Komitmen Kerja dan Keberlanjutan Kerja. Journal Of Business \& Applied Management, 11(2), p155238. DOI: http://dx.doi.org/10.30813/jbam.v11i2.1351

Priyanto, I. F. (2018). Menghadapi Era Normal Baru, KOMPAS. Retrieved from https://kompas.id/baca/opini/2018/02/03/menghadapi-era-normal-baru/

Rifngati, E. (2016). Tantangan Pustakawan Perguruan Tinggi Dalam Memberikan Layanan Prima dengan Berbasis Teknologi Informasi, Dinamika Penelitian, 16(2), p263-278. DOI: $10.21274 /$ dinamika.2016.16.2.268-273

Rulyah, S. (2018). Profesi Pustakawan: Tantangan dan Peluang. Jurnal Kepustakawanan dan Masyarakat Membaca, 34(1), p29-38. Retrieved from https://bit.ly/3ab1vVr

Sandercock, P. (2016) Instructor perceptions of student information literacy: comparing IL models to reality. Journal of Information Literacy 10(1), p3-29. DOI: https://doi.org/10.11645/10.1.2065

Shannon, C., Reilly, J. \& Bates, J. 2019. Teachers and information literacy: understandings and perceptions of the concept. Journal of Information Literacy 13(2), p.41-72 DOI: https://doi.org/10.11645/13.2.2642

Sumanti, D. A., \& Fauziah, K. (2017). Implementasi literasi informasi dalam pemenuhan kebutuhan informasi pemustaka di Perpustakaan Kementerian Pendidikan dan Kebudayaan. Jurnal Ilmu Informasi, Perpustakaan, dan Kearsipan, 19(2), p55-62. DOI: http://dx.doi.org/10.7454/jipk.v19i2.121

Setyowati, Lis. (2015). Literasi Informasi Dilihat dari Perspektif Modal Manusia. LIBRARIA: Jurnal Perpustakaan, 3(2), p232-246. DOI: 10.21043/libraria.v3i2.1594

Suwandi. (2017). Literasi abu-abu dalam perpustakaan, Iqra': Jurnal Perpustakaan dan Informasi, 11(1), p135-147. DOI: 10.30829/iqra.v11i01.785 
Webber, S. (2010). Information Literacy for the 21st Century. INFORUM 2010: 16th Conference on Professional Information Resources. Praha. 25-27 Mei 2010. Retrieved from http://www.inforum.cz/pdf/2010/webber-sheila-1.pdf

Wicaksono, A. (2016). Profil Literasi Informasi Pustakawan Indonesia, Berkala Ilmu Perpustakaan dan Informasi, 12(1), p1-9. DOI: 10.22146/bip.13024

Wright A. (2014). So What's the Big Deal With Information Literacy in the United States?. In: Chen C., Larsen R. (eds) Library and Information Sciences. Springer, Berlin, Heidelberg, p9-19. DOI: https://doi.org/10.1007/978-3-642-54812-3_2 